\title{
IMPACT OF LARGE HUMAN CONSTRUCTIONS ON A KARST RIVER HYDROLOGY: CASE OF THE CETINA RIVER (DINARIC KARST)
}

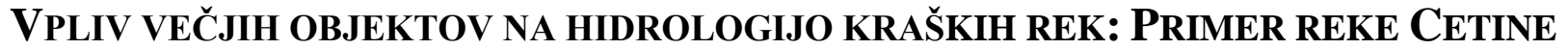 (DINARSKI KRAS)}

\section{Ognjen Bonacci ${ }^{1}$, Ivo Andrić ${ }^{1, *}$, Tanja Roje-Bonacci ${ }^{1}$, Dijana Oskoruš ${ }^{2}$, Adrijana Vrsalović $^{1}$}

${ }^{1}$ Split University, Faculty of Civil Engineering, Architecture and Geodesy, 21000 Split, Matice hrvatske 15, Croatia

${ }^{2}$ Meteorological and Hydrological Service, 10000 Zagreb, Ravnice 48, Croatia

\begin{abstract}
The paper studies drastic hydrological changes caused by construction of five reservoirs and six hydro-electric power plants (HEPP), built mostly in the 1960s, along the watercourse of the karst river Cetina, located in deep and well-developed Dinaric karst. The total river length from its spring to mouth in the Adriatic Sea is about $105 \mathrm{~km}$. Discharges are monitored at nine gauging stations and then compared using statistical methods. Discharges measured before construction of hydraulic structures were compared with discharges measured afterwards. Analysis of the results determined that the complex natural hydrologic regime has been completely destroyed. The hydrology of the upper river, from the spring to the Prančevići Dam (length of about $65 \mathrm{~km}$ ), is changed by the development and operation of the Peruča Reservoir and the Peruča HEPP, as well as the Lipa and the Buško Blato Reservoirs and Buško Blato and Orlovac HEPPs. Water diversion from the Prančevići Reservoir through two tunnels and pipelines to power the Zakučac HEPP has dangerously altered hydrological regime of the Cetina River's $40 \mathrm{~km}$-long downstream section. In the 65-km long upstream section, the hydrological regime was altered immediately after the Peruča Reservoir was put into operation. In the downstream section the majority of natural flow is lost. The mean annual discharges dropped from more than $100 \mathrm{~m}^{3} \mathrm{~s}^{-1}$ to less than $10 \mathrm{~m}^{3} \mathrm{~s}^{-1}$. Due to HEPPs operation, minimum annual discharges have drastically and dangerously decreased.
\end{abstract}

Keywords: karst river hydrology, hydro-electrical development, the Cetina River, river regime alteration, Dinaric karst

\section{Izvleček}

Članek proučuje velike hidrološke spremembe, ki jih je povzročila izgradnja petih akumulacij in šestih hidroelektrarn (HE), večinoma izgrajenih v 60-ih letih prejšnjega stoletja, vzdolž kraške reke Cetine, ki leži v globokem, dobro razvitem dinarskokraškem svetu. Skupna dolžina reke od izvira do izliva v Jadransko morje je pribl. $105 \mathrm{~km}$. Meritve pretokov, ki potekajo na devetih merilnih postajah, smo primerjali z uporabo različnih

\footnotetext{
${ }^{1}$ Stik / Correspondence: ivo.andric@gradst.hr

(C) Bonacci O. et al.; This is an open-access article distributed under the terms of the Creative Commons Attribution - NonCommercial - ShareAlike 4.0 Licence.
}

(C) Bonacci O. et al.; Vsebina tega članka se sme uporabljati v skladu s pogoji licence Creative Commons Priznanje avtorstva Nekomercialno - Deljenje pod enakimi pogoji 4.0.

https://doi.org/10.15292/acta.hydro.2020.10 
statističnih metod. Pretoke, izmerjene pred izgradnjo hidrotehničnih objektov, smo primerjali s pretoki, izmerjenimi po njihovi izgradnji. Analiza rezultatov je pokazala, da je kompleksni naravni režim popolnoma uničen. Hidrologija zgornjega dela reke, od izvira do pregrade Prančevići (dolžine pribl. $65 \mathrm{~km}$ ), se je spremenila $\mathrm{z}$ razvojem in obratovanjem akumulacije in HE Peruča kot tudi akumulacij Lipa in Buško Blato ter HE Buško Blato in Orlovac. Preusmeritev vode iz akumulacije Prančevići prek dveh obtočnih tunelov in cevovoda za obratovanje HE Zakučac je nevarno spremenila hidrološki režim 40-kilometrskega dolvodnega odseka Cetine. V 65-kilometrskem gorvodnem odseku se je hidrološki režim spremenil takoj po začetku obratovanja akumulacije Peruča. Dolvodno se naravni tok reke večinoma ni ohranil. Srednji letni pretok je z več kot $100 \mathrm{~m}^{3} \mathrm{~s}^{-1}$ upadel pod $10 \mathrm{~m}^{3} \mathrm{~s}^{-1}$. Zaradi obratovanja hidroelektrarn se je minimalni letni pretok drastično zmanjšal na nevarno nizko raven.

Ključne besede: hidrologija kraških rek, razvoj na področju vodne energije, reka Cetina, sprememba vodnega režima, dinarski kras

\section{Introduction}

Rivers are our planet's most important water resources. They are dynamic systems with changes occurring over a range of time scales, from instantaneous to geological ones. The hydrological regime of karst rivers is generally very different in comparison to non-karst rivers systems. Conditions that govern flow in rivers through karst areas are generally very different in comparison to the ordinary rivers systems that exist in non-karst regions. Due to very high infiltration rates, overland and surface flow in karst environments is rare in comparison to non-karst terrains, which results in a less-developed network of karst open stream flows (Bonacci, 1987).

Karst river hydrological regimes depend strongly upon the interaction between the groundwater level (GWL) and surface water. The GWL in karst greatly depends upon the effective porosity of the karst matrix, while groundwater connections between different parts of karst massive and some open stream flows depend on the existence, features, and dimensions of karst conduits. Some of these conduits recharge, while some drain off water from the rivers in karst (Bonacci and Andrić, 2008). The great variability of surface and underground karst forms, the interplay of pervious and impervious layers, the fast and large range of the GWL rising and decreasing in the karst massif, intricate hydraulic conditions, i.e. the concurrence of fast turbulent flow and slow laminar flow effecting various hydrological behaviour in many sections along any karst river (Atkinson,
1977). The interdependency between GWL and surface water in a karst river occasionally, permanently, and suddenly changes with time and space. Each karst river is unique and needs an individual approach to analysing its hydrological characteristics and behaviour.

Water discharge regimes along any karst river exhibit significant differences in some sections and during certain increments of time and space. The natural behaviour of characteristic (minimum, mean and maximum) discharges along any karst river is more complicated than that of those in non-karst terrains (Bonacci, 1999; Bonacci et al., 2013). Extremely vulnerable karst ecosystems, environments, and social systems depending on rivers are under severe pressure along with the effects of climate change and the uncontrolled increase in water use.

Constructions in karst areas and especially in karst rivers, which have been quite extensive in the past two centuries, can cause, have caused, and will cause strong, sudden, unpredictable, immeasurable and extremely dangerous consequences (Bonacci, 2004; Calò and Parise, 2006; Bonacci and Andrić, 2010; Bonacci and Roje-Bonacci, 2015; Bonacci, Oštrić and Roje-Bonacci, 2018; Morán-Tejeda et al., 2012; Huđek et al, 2020). Some of these negative consequences occur instantaneously, while some emerge after years or decades. Detailed knowledge of karst river hydrology is a prerequisite for the sustainable management of its water resources, as well as for protecting dependant environments and ecosystems. 
Sinking, losing and underground streams are frequent karst phenomena. Their occurrence in karst terrains is more like a rule than an exception (Hess et al., 1989; Yuan, 1991; Prelovšek et al., 2008; Cavalera and Gilli, 2009). Occasionally, permanent water courses flow beyond the GWL, even for $50 \mathrm{~m}$ or more (Terzić et al., 2014). In literature these river sections are called "suspended" or "perched" (Bonacci, 1987).

The extreme heterogeneity of the karst surface and underground media makes it difficult to investigate and explain karst river hydrology. Barberá and Andreo (2015) emphasize: "In riverine karst areas, surface water interacts with the groundwater flowing through carbonate aquifers. Understanding the interference of water fluxes in this type of environments is essential to effectively manage the groundwater resources, particularly in areas where karst aquifers comprise the main source of drinking water."

Over the about past 100 years, rivers in karst environments have suffered the single most intense onslaught of all planetary ecosystems. Pressures caused by human and natural factors on river karst ecosystems have increased with unstoppable force (Huđek et al., 2020). This paper studies hydrological changes caused by the construction of five reservoirs, water diversion works, and six hydro-electric power plants (HEPP) along the watercourse of the karst river Cetina. The investigations reported in this paper aim to broaden our previous work (Bonacci and Roje-Bonacci, 2003). The objective of this paper is to present to the international scientific community the consequences that uncontrolled, mass-scale anthropogenic actions have wrought on an exceptional karst river. We hope that illustrating the facts up will help in raising general awareness about the effects of human activity in karst river management.

\section{Materials and methods}

\subsection{Study area}

The Cetina River is a typical Mediterranean karst river that drains one of the major basins of the Dinaric karst. The entire river-course, at a length of about $105 \mathrm{~km}$ from the spring to the mouth in the Adriatic Sea, is completely located in Croatia. Its catchment is positioned in Croatia and Bosnia and Herzegovina (Figure 1).

The catchment spans between $43^{\circ} 20^{\prime}-44^{\circ} 15^{\prime} \mathrm{N}$ and $16^{\circ} 15^{\prime}-17^{\circ} 30^{\prime} \mathrm{E}$. About one-third of the catchment is in Croatia, while about two-thirds of the catchment is in Bosnia and Herzegovina. The recharge area is estimated to cover between 3700 $\mathrm{km}^{2}$ and $4300 \mathrm{~km}^{2}$ (Srebrenović, 1963; Baučić, 1967; Magdalenić, 1971; Stepinac, 1980). Precisely defining the catchment area (drainage basin, watershed or recharge area) in karst is an extremely complex task, which very often cannot be satisfactorily solved. The Cetina River catchment, like many other karst catchments, varies with variation in GWL. The human interventions described in the paper (dams, reservoirs, HEPP operation, water transfer) introduced changes in the Cetina River catchment area, but this crucial issue has not been analysed at all. The most probable Cetina River basin limit is presented in Figure 1, in which the state boundary between Croatia and Bosnia and Herzegovina is drawn (UNEP/MAP/PAP, 2000). At the same time, this line generally represents boundary between the indirect and the direct part of the catchment. They are separated by mountain chains reaching $1500 \mathrm{~m}$ a.s.l.

The basin is placed in a deep karst terrain formed of intensively karstified limestone and dolomites. Carboniferous deposits were formed during the Tertiary, Jurassic, and Cretaceous periods. According to their hydrogeological characteristics, Tertiary deposits could be divided into Paleogene and Neogene deposits. While the Paleogene ones, which are represented by limestone and marl clastites, do not constitute a barrier, the Neogene ones are a completed barrier formed of marl facies (UNEP/MAP/PAP, 2000). Concerning hydrogeological and hydrological characteristics, its drainage basin consists of two parts. The eastern indirect part, located mainly in Bosnia and Herzegovina, is connected with the western direct part located in Croatia by underground flow only. Karst poljes play a crucial role in water circulation inside the Cetina River catchment. The whole 
catchment area contains twelve karst poljes, located in its indirect part (Sackl et al., 2014). They are most often covered by soil belonging to the Neogene and Quarternary sediments, i.e. "terra rossa" (red soil). The four largest and the most important for water circulation are presented in Figure 1: (1) KP 1 Livanjsko Polje ( $\mathrm{A}=408 \mathrm{~km}^{2}, \mathrm{H}=709-808 \mathrm{~m}$ a.s.l.); (2) KP 2 - Duvanjsko Polje $\left(\mathrm{A}=125 \mathrm{~km}^{2}, \mathrm{H}=860\right.$ 900 m a.s.l.); (3) KP 3 - Glamočko Polje (A=62.4 $\mathrm{km}^{2}$. H=880-930 m a.s.1.); (4) Kupreško Polje $\left(\mathrm{A}=81.2 \mathrm{~km}^{2}, \mathrm{H}=1100-1200 \mathrm{~m}\right.$ a.s.1.). The other eight karst poljes have relatively small surface areas and do not play an important role in water transfer from the indirect to the direct part of the Cetina River catchment. In the direct part of the catchment, there are five poljes mostly located along the Cetina river course.
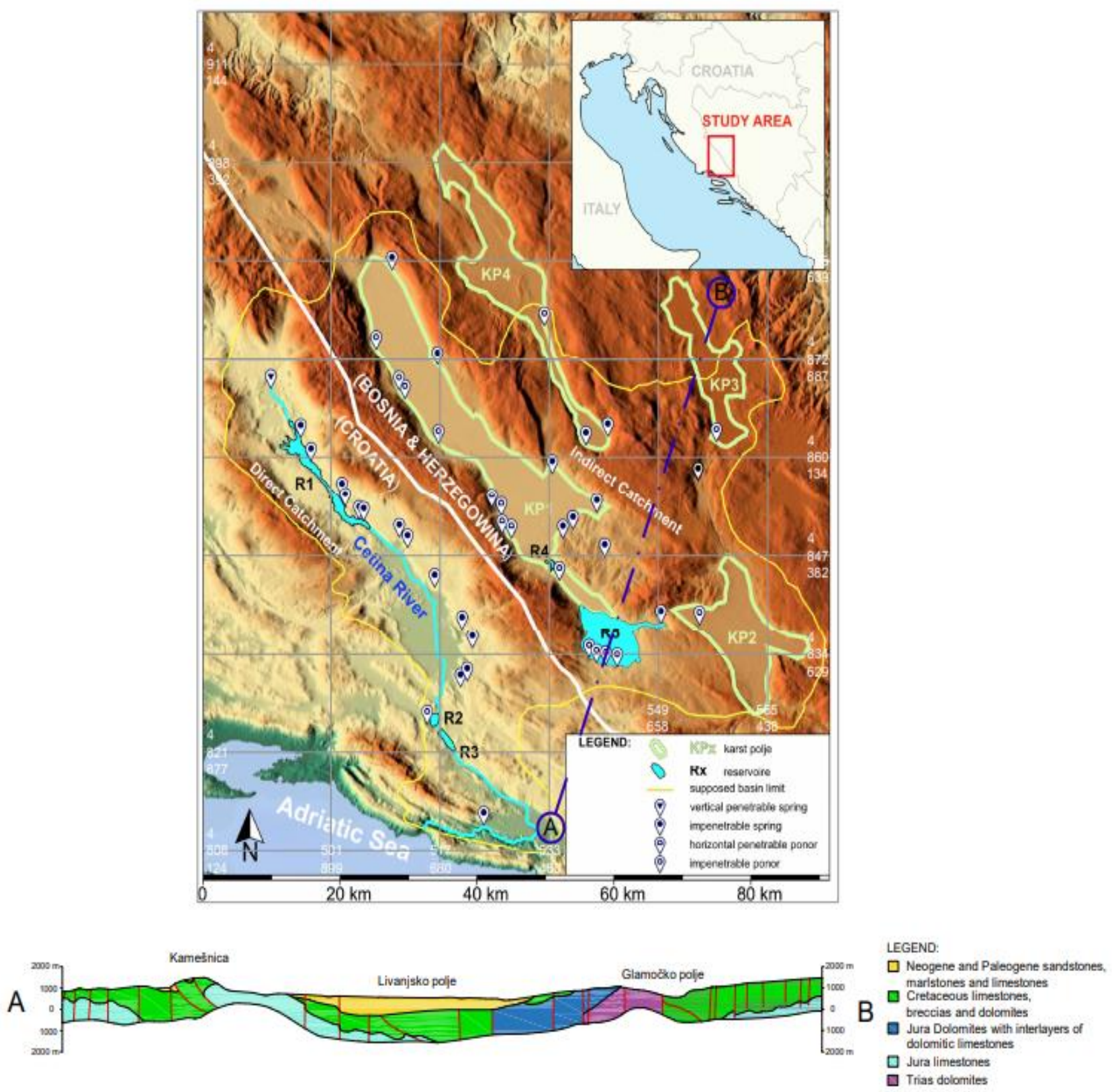

Figure 1: Study area location map and sketch of geological cross section A-B (partly after Basic Geological Map of SFRY 1:100000, sheet: Sinj).

Slika 2: Lokacijska karta območja obravnave in skica geološkega prereza A-B (delno po Osnovni geološki karti SFRJ 1 : 100 000, list: Sinj). 
Karst poljes are flat alluvial valleys bordered by steep, mostly bare, limestone ridges with permanent or temporary karst springs and rivers (Bonacci, 1987; LeGrand, 1983; Milanović, 1981; Ford and Williams, 2007). In the Dinaric karst, they are regularly flooded in the cold and wet periods of the year, from October to April. From a hydrogeologic point of view, a polje is a part of a wider system. It is a subsystem in the process of surface water and groundwater movement through catchment areas (López Chikano et al., 2002).

In the Cetina River catchment. poljes, especially those four marked in Figure 1, govern the development of the river's hydrological regime. Abysses or swallow holes are fissures in the karst mass through which water sinks underground (Field, 2002; Bonacci, 2013). They play an important role in the transport of surface water from poljes located in the indirect part of the catchment to the springs along the Cetina river course (designated in Figure 2 with Greek letters $\alpha, \beta, \gamma, \delta$, $\varepsilon, \zeta, \eta, \theta)$.

Locations of horizontal penetrable and impenetrable ponors and vertical penetrable and impenetrable springs are drawn in Figure 1. The most frequent ponors are situated close to the margins of a polje's minimum altitude. When the GWL in the surrounding karst aquifer is higher than the surface water in the pre-ponor retention, they act like a spring. This sort of ponor is called either an estavelle or inversac.

The climate is directly influenced by altitude and by distance from the Adriatic Sea. The climate of the catchment's western direct part is maritime, influenced by the Mediterranean climate. The Dinaric chain of mountains acts as a climate barrier. Because of that, the climate of the north-eastern indirect part of the catchment is generally continental. The average annual precipitation in the catchment is $1380 \mathrm{~mm}$. In the direct part of the catchment, the average annual air temperature varies between $11^{\circ} \mathrm{C}$ and $13{ }^{\circ} \mathrm{C}$, and in the indirect between $6^{\circ} \mathrm{C}$ and $8^{\circ} \mathrm{C}$ (Bonacci, 2001).
One of the main karst open streams characteristic is that they either completely sink into the underground or have partial water losses along their course. In particular sections, the losses can be abundant, whereas in others they are small. The losses mainly depend on hydrogeologicalhydrological conditions, especially of GWL in surrounding karst aquifer (Bonacci, 1999). The Cetina River is not an exception to this rule; in the lower part, downstream from the Prančevići Reservoir, there are few sections in which water sinks during the low water period. The natural processes of water losses along these sections are strongly influenced by weak human interventions, but the problem is that there is no control at all. Various analyses of different aspects (geographical, geological, engineering, biological, ecological, social, etc.) dealing with the Cetina River and catchment have been published in several papers (e.g. Stepinac, 1980; UNEP/MAP/PAP, 2000; Vučković et al., 2009; Sackl et al., 2014). Despite this, importantly the Cetina River and catchment have not been analysed well enough. Definitely, the need for additional comprehensive and interdisciplinary monitoring and analysis is crucial in order to protect this endangered landscape. Hydrological information and the conclusion given in this paper will be key for all the other approaches.

Drastic and environmentally extremely dangerous hydrological changes along the Cetina River are caused by the construction of dams and reservoirs, the operation of HEPPs, and the transfer of water by tunnels and pipelines. The basic data of seven HEPPs are given in Table 1. 


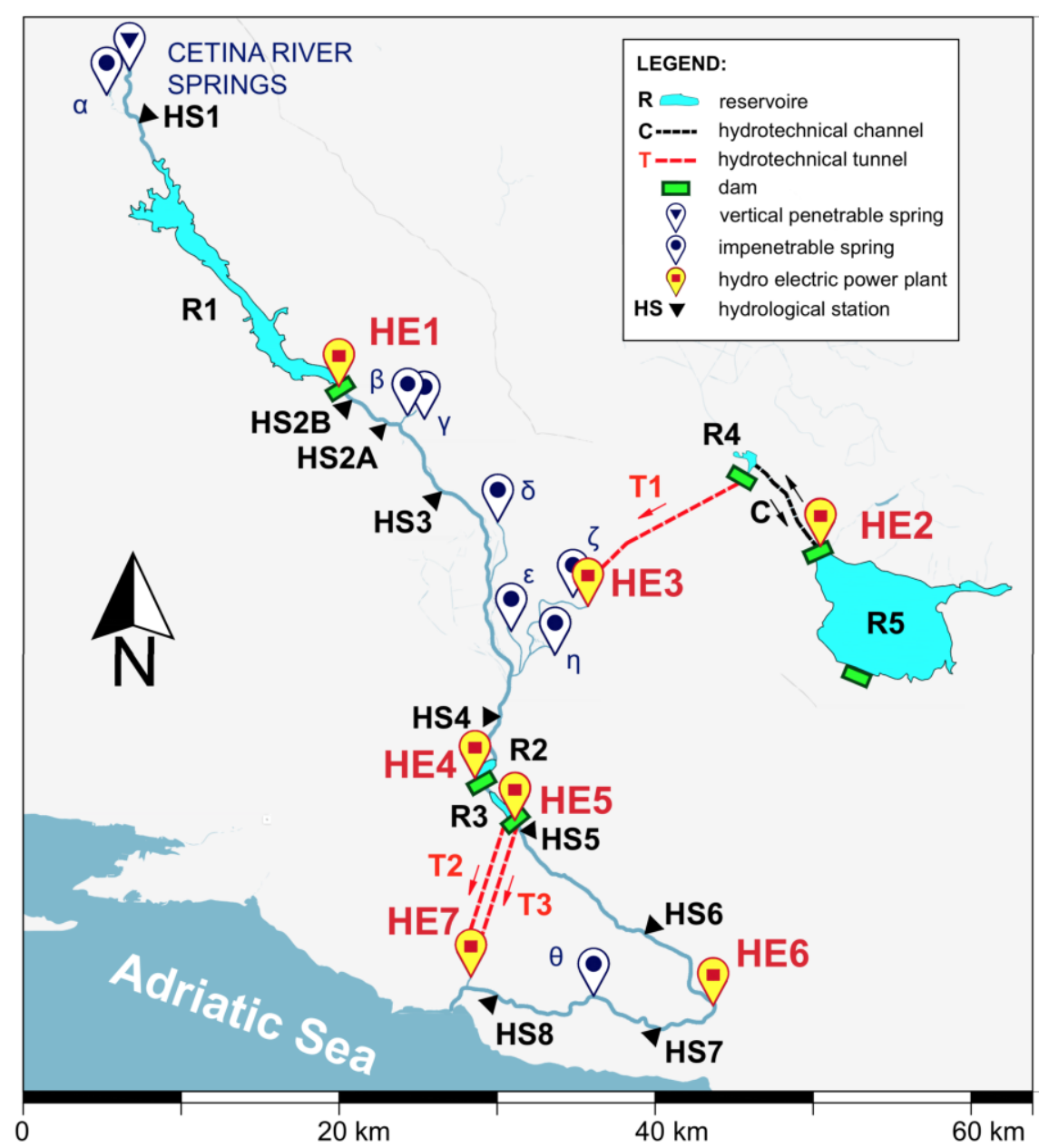

Figure 3: Location map of the Cetina River indicating: (1) springs $(\alpha-\theta)$; (2) hydrological stations (HS1HS8); (3) reservoirs (R1-R5); (4) dams; (5) HEPPs (HE1-HE7); (6) tunnels (T1-T3); (7) channel (C).

Slika 4: Lokacijska karta reke Cetine: (1) izviri ( $\alpha-\theta)$; (2) hidrološke postaje (HS1-HS8); (3) akumulacije (R1-R5); (4) pregrade; (5) HE (HE1-HE7); (6) obtočni tuneli (T1-T3); (7) kanal (C).

Table 1: Basic data of HEPPS.

Preglednica 2: Osnovni podatki o hidroelektrarnah.

\begin{tabular}{ccccc}
\hline HEPP Name & $\begin{array}{c}\text { Notation in } \\
\text { Figure } 2\end{array}$ & $\begin{array}{c}\text { Start of } \\
\text { Operation }\end{array}$ & $\begin{array}{c}\text { Installed } \\
\text { Discharge }-\mathrm{Q}\left(\mathrm{m}^{3} \mathrm{~s}^{-1}\right)\end{array}$ & $\begin{array}{c}\text { Useful Reservoir } \\
\text { Volume }-\mathrm{V}\left(10^{6} \mathrm{~m}^{3}\right)\end{array}$ \\
\hline Peruča & HE1 & 1960 & 120 & $503 ; 565^{*}$ \\
Buško Blato & HE2 & 1974 & 70 & 782 \\
Orlovac & HE3 & 1973 & 70 & 782 \\
Đale & HE4 & 1989 & 220 & 2.6 \\
Prančevići & HE5 & 2017 & 6 & 2.6 \\
Kraljevac & HE6 & 1912 & 80 & 0.1 \\
Zakučac & HE7 & 1962 & $120^{\circ}$ & 4.4 \\
\hline
\end{tabular}

*Volume after the 2008 dam reconstruction; • The first tunnel and pipeline (T2); •*The second tunnel and pipeline (T3) 
Table 3: Main characteristics of the analysed hydrological stations along the Cetina River.

Preglednica 4: Poglavitne značilnosti analiziranih hidroloških postaj na Cetini.

\begin{tabular}{|c|c|c|c|c|c|}
\hline Station Name & $\begin{array}{l}\text { Notation } \\
\quad \text { in } \\
\text { Figure 2 }\end{array}$ & $\begin{array}{r}\text { Elevation } \\
\text { (m a.s.1.) }\end{array}$ & $\begin{array}{l}\text { Distance from } \\
\text { the mouth }-\mathrm{L} \\
(\mathrm{km})\end{array}$ & Available Period & Missing Data \\
\hline Vinalić & HS1 & 336.39 & 97.94 & Jan.1946-Dec.2018 & $\begin{array}{c}\text { Jul.-Aug.1977; } \\
\text { Jul.-Dec.1978; } \\
\text { Aug.1991-Mar.1997 }\end{array}$ \\
\hline Šilovka & HS2B & 301.45 & 75.15 & Jan.1959-Dec.2018 & Aug.1991-May1992 \\
\hline Panj & HS2A & 300.57 & 72.65 & Jan.1947-Dec.1958 & - \\
\hline Han & HS3 & 296.63 & 64.50 & Jan.1947-Dec.2018 & - \\
\hline $\begin{array}{c}\text { Gardunska } \\
\text { mlinica }\end{array}$ & HS4 & 284.24 & 47.95 & Jan.1947-Dec.1987 & - \\
\hline Čikotina lađa & HS5 & 240.66 & 37.30 & Jan.1947-Dec.2018 & Jan.1956-Dec.1979 \\
\hline Blato na Cetini & HS6 & 197.46 & 27.25 & Jan.1947-Dec.2018 & - \\
\hline Pavića most & HS7 & 47.84 & 17.10 & Jan.1947-Dec.2018 & - \\
\hline Tisne stine & HS8 & 6.60 & 1.20 & Jan.1947-Dec.2018 & - \\
\hline
\end{tabular}

\subsection{Data used}

Daily, monthly, and annual discharge data, based on daily measurements at nine hydrologic gauging stations from 1946-2018, following international standards, were collected by the Croatian Meteorological and Hydrological Service. Since the length of the data series depends on the date of dam construction, some series have had inhomogeneity and missing data. The locations of nine hydrological stations are shown in Figure 2 (HS1-HS8), while their main characteristics are listed in Table 2.

In this study, classical statistical methods were used for the hydrological analysis of the annual and monthly time series of characteristic (minimum, mean and maximum) discharges measured at nine hydrological stations along the Cetina River. Of special importance is to stress that the minimum and maximum discharges along the river course react differently to construction works as well as to HEPPs.

\subsection{Trend analysis}

Analysing a long time series, we try to explain the different changes in the analysed characteristics (minimum, mean and maximum) of monthly and annual discharges. The goal of this investigation is to better understand the effect of anthropogenic construction and the operation of the natural hydrological regime. The Mann Kendall Trend test (M-K test) is used to analyse data collected over time for consistently (monotonic) increasing or decreasing trends (Mann, 1945; Kendall, 1975). The linear regression analyses and non-parametric $\mathrm{M}-\mathrm{K}$ test were used to calculate the statistical significance of the temporal trends in the time series of the mean and maximum annual and monthly discharges measured at some hydrological stations in long time discharge series. The test can be used to find trends for as few as four samples. The null hypothesis for this test is that there is no monotonic trend in the series. The alternate hypothesis is that the trend exists. This trend can be positive, negative, or non-null.

\subsection{Differences between two time subseries}

The F-test and t-test were used to calculate how significant the differences between two mean annual and monthly discharge time subseries are. In statistics, an F-test of the variance equality is a test for the null hypothesis that two normal populations have the same variance. A t-test is a type of inferential statistic used to determine whether there is a significant difference between the means of two groups, which may be related to certain features. These two tests helped us compare quantitatively whether these two discharge time subseries (before and after the transfer of water, construction and 
operation of some reservoirs and HEPPs) have statistically significant differences in average values.

\section{Results and discussion}

It is realistic to expect that many constructions, as well as other anthropogenic activities taken in the Cetina River and catchment (described in previous chapter) started in the autumn of 1960, have had large or low influence on the river hydrological regime. The following three had the strongest influence on discharge regime of eight gauging stations located along the river-course: (1) Peruča Reservoir and HEPP development (start of operation autumn 1960); (2) Buško Blato Reservoir (start of operation at the end of 1972); (3) water diversion from Prančevići Reservoir to Zakučac HEPP (the first tunnel and pipe line started operating in 1961, and the second in 1981). Only one discharge gauging station, Vinalić (HS1), is located upstream from the Peruča Reservoir. Discharges monitored at the hydrological stations Šilovka (HS2B) and Panj (HS2A) are treated as one since there is no recharge between them.

\subsection{Natural state}

The first HEPP in the Cetina river-course Kraljevac (HE6 in Figure 2) was built in 1912, using the Gubavica waterfall head. Since its location is $21 \mathrm{~km}$ distance from the mouth and its production is relative, its operation did not disturb the river's natural hydrological regime. The prominent disturbance started with the construction and operation of the Peruča dam, reservoir, and HEPP, which was commissioned was in autumn 1960. This subchapter will focus on a comprehensive analysis of available hydrological data along the Cetina River in the period from 1946 to 1960, i.e. during the undisturbed hydrological regime.

Figure 3 shows the series of minimum (Figure 3a), mean (Figure 3b) and maximum annual (Figure 3c) discharges in the period before the Peruča HEPP development (1946-1960), i.e. during the natural state.

A sudden drop of minimum annual discharges (Figure 3a) can be noted within three years (19581960) at all stations downstream from the Peruča Reservoir. This can be explained by construction work on the construction of Peruča Dam, which began in 1958. The drop did not occur at the Vinalić gauging station, only one station upstream from the Peruča Reservoir.

Seven time series of the mean annual discharges (Figure 3b) show regular hydrological behaviour, i.e. growth of discharges along the Cetina river course. From the time series of the maximum annual discharges (Figure 3c), it can be seen that the maximum annual discharges increase up to the Gardunska Mlinica station. At the other downstream station commencing with Čikotina Lađe (HS5), the maximum annual discharges are practically the same as at Gardunska Mlinica. The reason is that downstream from the inflow of the Ovrlja ( $\varepsilon$ in Figure 2), Ruda ( $\zeta$ in Figure 2), and Grab ( $\eta$ in Figure 2) springs there is no concentrated inflow along the river course able to increase the peak of the hydrograph, i.e. maximum discharge. 

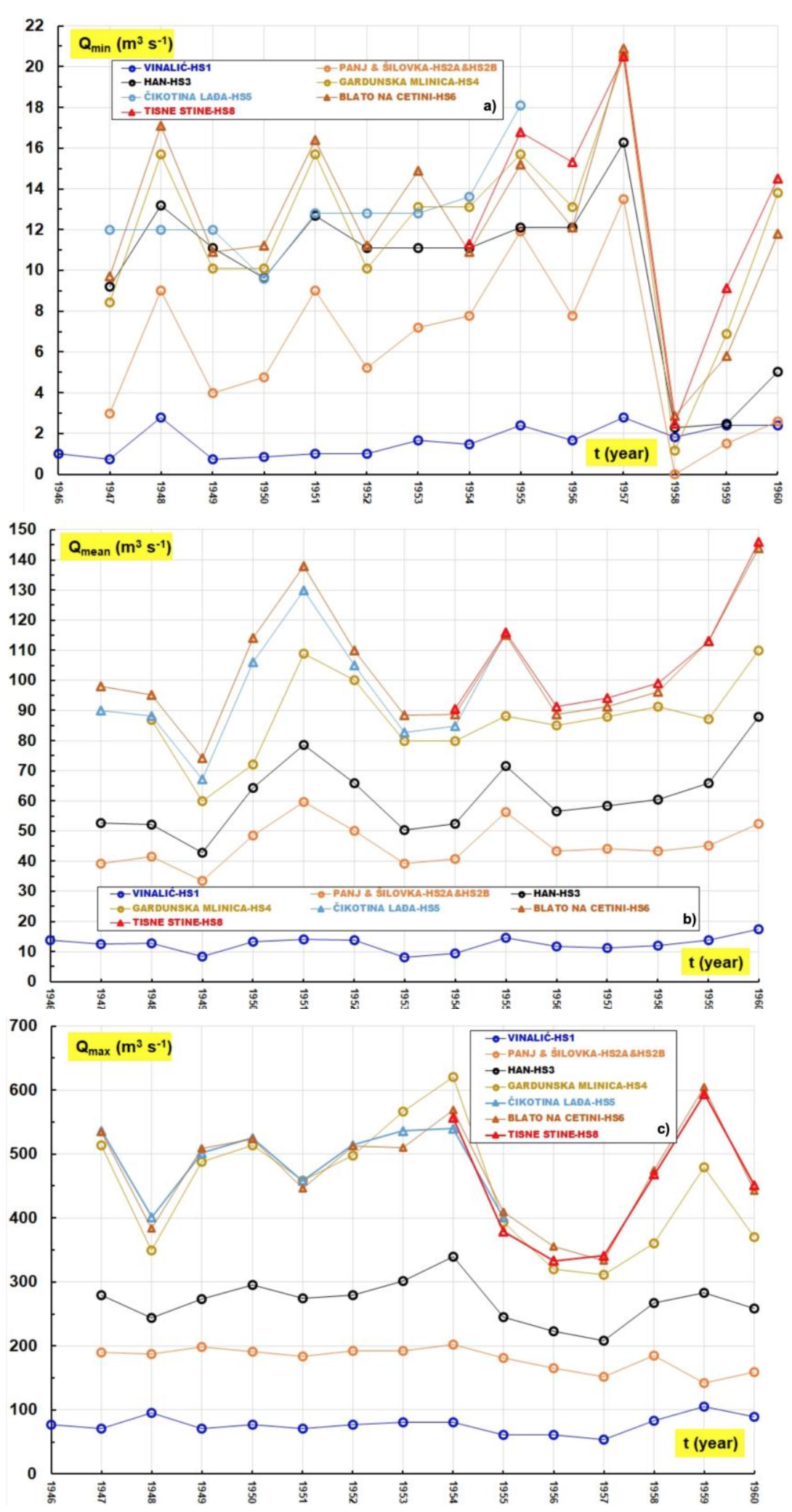

Figure 5: Time series of annual minimum (Figure 3a), mean (Figure 3b), and maximum (Figure $3 c$ ) discharges measured at available hydrological stations along the Cetina River during the natural state in the period from 1946 to 1960.

Slika 6: Časovna vrsta letnih minimalnih (slika 3a), srednjih (slika 3b) in maksimalnih (slika 3c) pretokov, izmerjenih na razpoložljivih hidroloških postajah vzdolž Cetine v naravnem stanju v obdobju od 1946 do 


\subsection{Influence of the Peruča Reservoir and Peruča's HEPP development}

The Cetina River's natural hydrological regime was firstly and irrevocably disrupted with the construction of the dam and Peruča reservoir, as well as with the operation of the HEPP. The Peruča HEPP (HE1 in Figures 1 and 2) is located about 25 $\mathrm{km}$ downstream from the Cetina River spring or 80 $\mathrm{km}$ upstream from its mouth to the Adriatic Sea. The large reservoir (see Table 1) and high hydroelectrical production prominently influenced the downstream hydrological regime. The significant changes of discharges were noted at the following hydrological stations: (1) Panj (HS2A) and Šilovka (HS2B); (2) Han (HS3).

The first two hydrological gauging stations downstream from the Peruča Reservoir are Panj (HS2A) and Šilovka (HS2B). At the Panj station, located about $7.3 \mathrm{~km}$ downstream from the Peruča Dam, discharges were monitored in the period from 1947 to 1958 . The Šilovka station, located $2.35 \mathrm{~km}$ upstream from the Panj station, was established in December 1958 and has been operating ever since. As there is no gain nor loss in flow between these two locations their discharges are treated as one. The Han (HS3) station is located $10.65 \mathrm{~km}$ downstream from the Šilovka station. Downstream from the Han hydrological station the Cetina River hydrological regime is less influenced by the Peruča dam, reservoir, and HEPP due to the inflow of abundant karst springs ( $\alpha$ to $\zeta$ in Figure 2 ).

Figure 4 depicts the time series of annual minimum discharges measured at three hydrological stations
(HS1, HS2A and HS2B, HS3) downstream from the Peruča reservoir and HEPP during the period from 1946 to 2018.The hydrological regime of minimum annual discharges at the Vinalić (HS1) station is not disrupted by the construction and operation of the Peruča dam, reservoir, or HEPP. During the natural state (1947-1957), the average minimum discharge of Panj and Šilovka (HS2A and HS2B) was $7.6 \mathrm{~m}^{3}$ $\mathrm{s}^{-1}$. With the beginning of the Peruča Dam's construction from 1958 it has dropped to $2.3 \mathrm{~m}^{3} \mathrm{~s}^{-1}$. At the Han (HS3) station the average minimum annual discharge in the period of the natural state (1947-1957) was $11.7 \mathrm{~m}^{3} \mathrm{~s}^{-1}$, and after that it dropped to less than half of that, namely to only 4.7 $\mathrm{m}^{3} \mathrm{~s}^{-1}$. The reason is the Peruča HEPP. In both cases the results of the t-test showed an extreme statistically significant difference $(p<<0.01)$ between the average values of discharges in the analysed subperiods.

Figure 5 shows the time series of monthly minimum (Figure 5a), mean (Figure 5b), and maximum (Figure 5c) discharges measured at the Panj and Šilovka (HS2A and HS2B) hydrological stations before and after Peruča HEPP began operating, during the following two subperiods: (1) 19471960; (2) 1961-2018.

The influence of the Peruča HEPP has been fully observed. The average minimum monthly discharges (Figure 5a) have drastically diminished during the whole year. The average mean and maximum monthly discharges (Figures $5 b$ and $5 c$ ) have almost been equalized. 


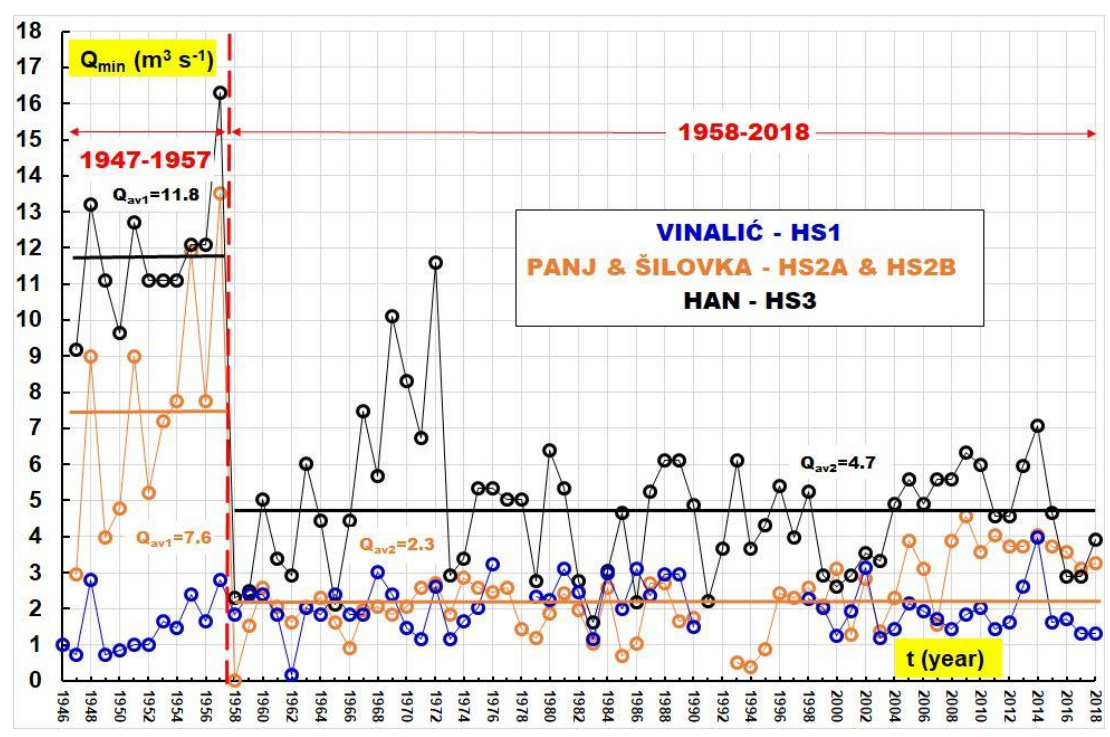

Figure 7: Time series of annual minimum discharges measured at three hydrological stations (HS1) upstream and (HS2A and HS2B, HS3) downstream from the Peruča reservoir and HEPP during the period from 1946 to 2018.

Slika 8: Časovna vrsta letnih minimalnih pretokov, izmerjenih na treh hidroloških postajah (HS1) gorvodno in (HS2A in HS2B, HS3) dolvodno od akumulacije in HE Peruča v obdobju od 1946 do 2018.
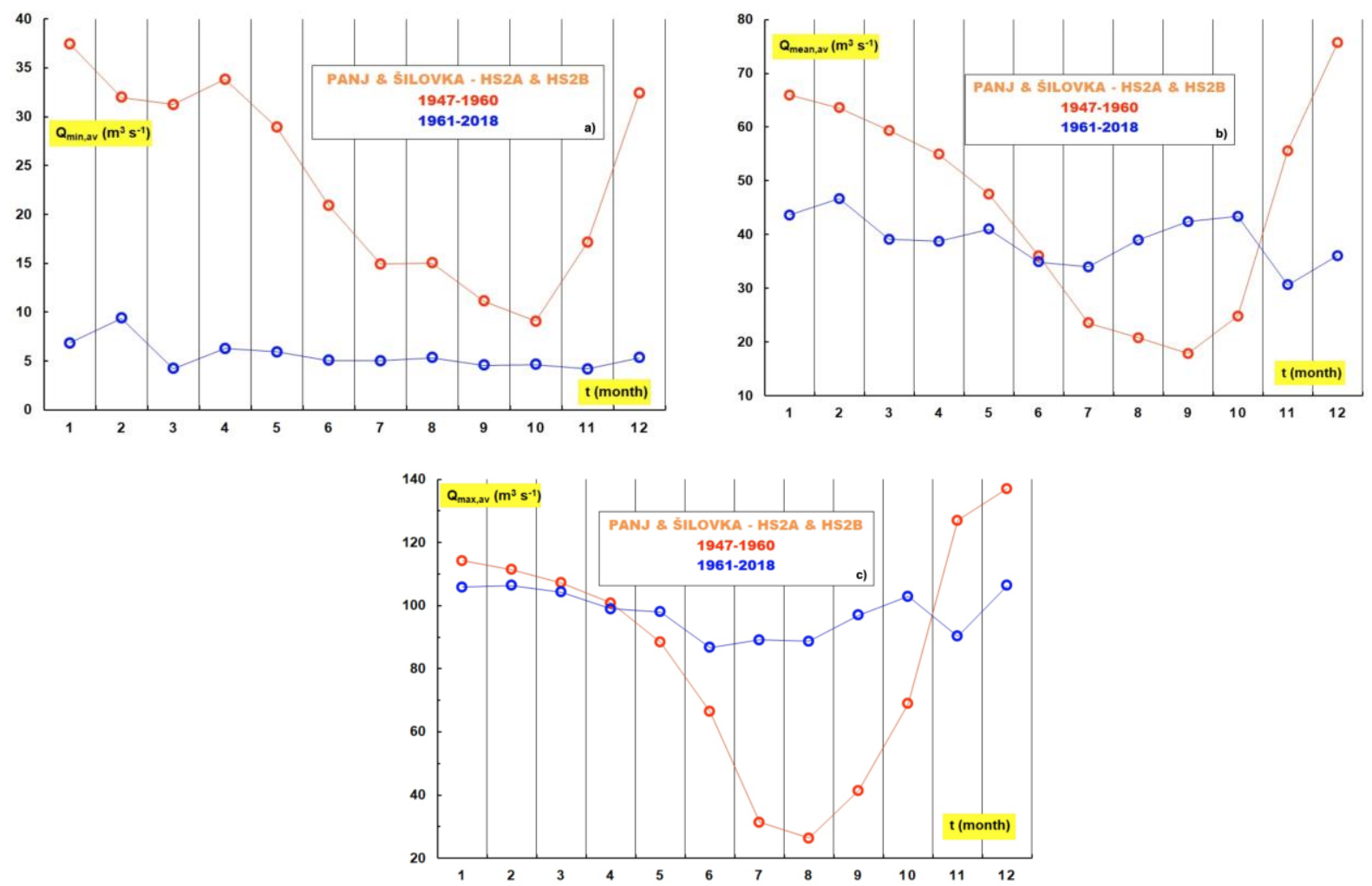

Figure 9: Time series of monthly minimum (Figure 5a), mean (Figure 5b), and maximum (Figure 5c) discharges measured at the Panj and Šilovka (HS2A and HS2B) hydrological stations during two subperiods: (1) 1947-1960; (2) 1961-2018.

Slika 10: Časovna vrsta mesečnih minimalnih (slika 5a), srednjih (slika 5b) in maksimalnih (slika 5c) pretokov, izmerjenih na hidroloških postajah Panj in Šilovka (HS2A in HS2B) v dveh podobdobjih: (1) 1947-1960; (2) 1961-2018. 


\subsection{Influence of Buško Blato Reservoir}

In the indirect part of the Cetina catchment in Bosnia and Herzegovina at the south-western part of the Livanjsko Polje, the Buško Blato Reservoir (R5 in Figures 1 and 2) was impounded with active storage of $786 \cdot 106 \mathrm{~m}^{3}$. The average water level in the reservoir is $716.4 \mathrm{~m}$ a.s.l. The water stored in this reservoir is conveyed through the hydrotechnical channel ( $\mathrm{C}$ in Figure 2) into the Lipa Reservoir ( $\mathrm{R} 4$ in Figures 1 and 2), which is a compensation reservoir for the Orlovac HEPP (HE3 in Figures 1 and 2) located in Croatia. The water used for hydro-power generation in the Orlovac HEPP is discharged thought an open channel into the Ruda River, which is the left tributary of the Cetina River. In the natural state, this reservoir was the karst polje Buško Blato regularly flooded during the wet and cold season, between October and April. The Buško Blato Reservoir began operations in 1973. It was created with the construction of five deep and large grout curtains and two embankments upstream from five main ponor zones in order to prevent water losses from the reservoir. The water losses from the reservoir have been reduced but not entirely eliminated. The above-mentioned very expensive engineering constructions were not able to protect the reservoir from water storage (Bonacci, Gottstein and Roje-Bonacci, 2009; Bonacci and Roje-Bonacci, 2012; Bonacci, 2015). The construction of the Buško Blato Reservoir changed the water regime of the all springs (designated as $\beta$, $\gamma, \delta, \varepsilon, \zeta, \eta$ in Figure 2) on the left bank of the Cetina River. A significant drop in the minimum, mean and maximum annual discharges at all the abovementioned springs has been caused by the Buško Blato Reservoir formation (Bonacci, Roje-Bonacci, 2003; Bonacci et al., 2016).

Figure 6a shows three time series of mean annual discharges with linear trend lines in the period from 1946 to 2018.

In all the analysed stations the linear regression lines show a statistically significant decreasing trend. Results of the M-K test are: (1) at HS1 p=1.7E-03; (2) at HS2A and HS2B p=1.6E-03; (3) at HS3 $\mathrm{p}=1.4 \mathrm{E}-03$. Influence of the Buško Blato Reservoir construction can be seen analysing the differences of average discharges during two subperiods: (1) before the Buško Blato Reservoir construction 1947-1972; (2) after the Buško Blato Reservoir construction 1973-2018. Results of the t-tests are: (1) at HS1 p=0.0192; (2) at HS2A and HS2B $\mathrm{p}=1.3 \mathrm{E}-04$; (3) at HS3 $\mathrm{p}=6.3 \mathrm{E}-06$.

Figure $6 \mathrm{~b}$ shows three time series of maximum annual discharges with linear trend lines in the period from 1946 to 2018. Statistically significant decreasing trends were established only at HS2A and HS2B and HS3 hydrological stations. Results of the M-K test are: (1) at HS1 p=0.399; (2) at HS2A and HS2B p=8.0E-05; (3) at HS3 p=2.0E-03. Average values of maximum annual discharges at HS2A and HS2B and HS3 hydrological stations before and after the Buško Blato construction are statistically significant. Results of the t-tests are: (1) at HS1 $\mathrm{p}=0.943$; (2) at HS2A and HS2B p=5.9E-05; (3) at HS3 p=2.0E-05.

\subsection{Influence of water diversion from Prančevići Reservoir to Zakučac HEPP}

The Prančevići Dam and Reservoir (R3 in Figures 1 and 2) on the Cetina River was built in 1962. It is a compensation reservoir for the Zakučac HEPP (HE7 in Figure 2). The water from the Prančevići Reservoir is conveyed to the Zakučac HEPP turbines by two pressure tunnels long $9,876 \mathrm{~m}$ (right tunnel) and 9,894 $\mathrm{m}$ (left tunnel) and two penstocks, $289 \mathrm{~m}$ each. The first tunnel and pipeline were built in 1962, and the second ones were built in 1980. In the $40 \mathrm{~km}$ long section of the Cetina river-course, downstream from the Prančevići Dam to the Cetina River mouth, hydrological regime depends on water redirection in the Zakučac HEPP. According to the rules, ecologically acceptable flow, which should be released from the reservoir, is $8 \mathrm{~m}^{3} \mathrm{~s}^{-1}$.

Figures 7 depicts time series of annual minimum (Figure 7a), mean (Figure 7b) and maximum (Figure 7c) discharges measured at hydrological stations Blato na Cetini (HS6), during the period from 1947 to 2018. 

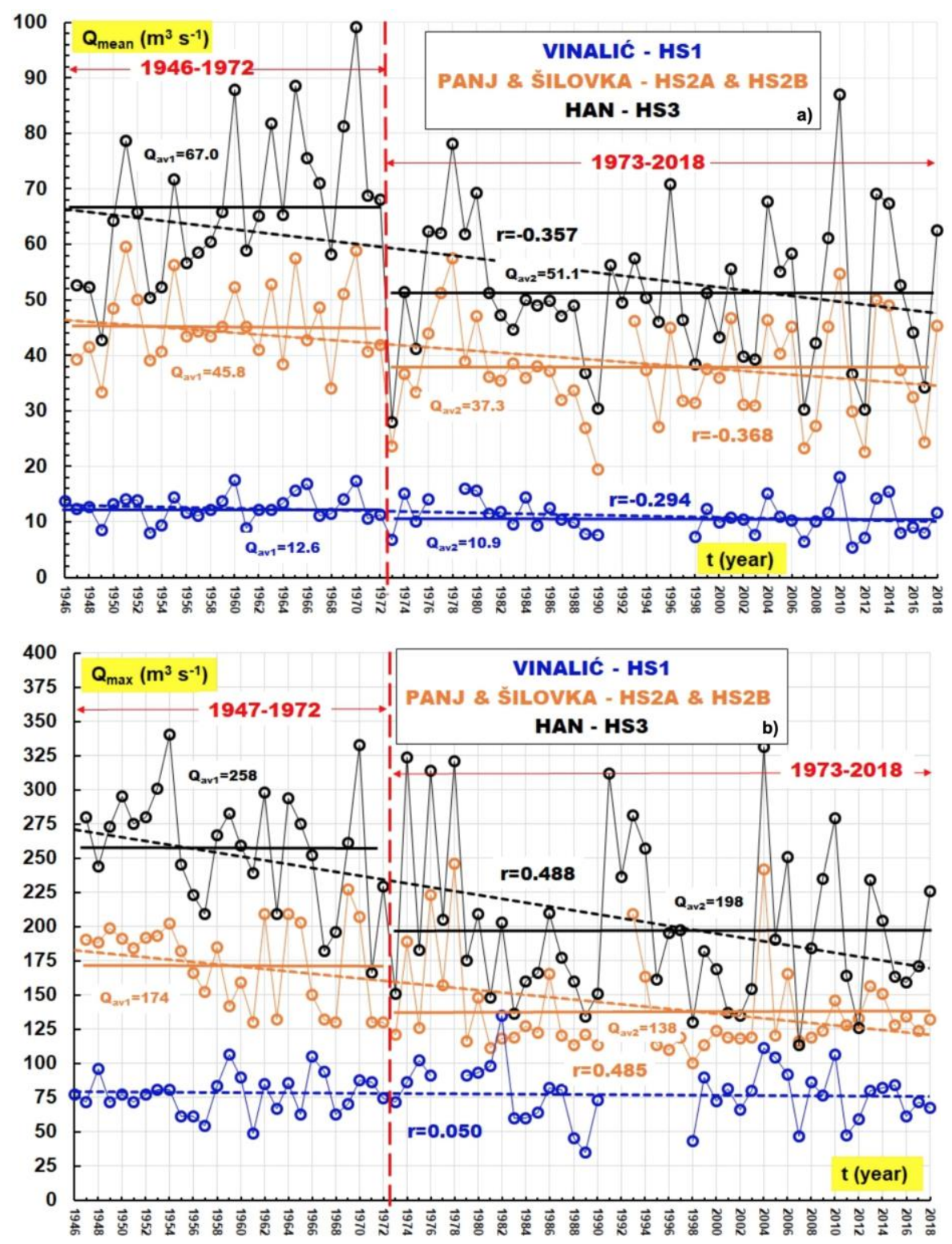

Figure 11: Time series of the annual mean (Figure 6a) and maximum (Figure 6b) discharges measured at the hydrological stations Panj and Šilovka (HS2A and HS2B) during two subperiods: (1) 1947-1960; (2)

1961-2018.

Slika 12: Časovna vrsta letnih srednjih (slika 6a) in maksimalnih (slika 6b) pretokov, izmerjenih na hidroloških postajah Panj in Šilovka (HS2A in HS2B) v dveh podobdobjih: (1) 1947-1960; (2) 1961-2018.

The minimum annual time series (Figure 7a) is divided into the following three time subseries: (1) natural state 1947-1960; (2) after the construction of the Prančevići Reservoir 1961-2002; (3) years 2003-2018. The average values at these three subperiods have statistically significant differences. Results of the t-test for the average values of the first and the second subperiod are $\mathrm{p}=6.0 \mathrm{E}-07$. Between the averages of the second and the third subperiods, the results of the t-test are $\mathrm{p}=3.2 \mathrm{E}-09$. The drastic drop, which occurred in the second subperiod
(1961-2002), was caused by the Zakučac HEPP. The jump of average value in the third subperiod of about $4 \mathrm{~m}^{3} \mathrm{~s}^{-1}$ is the result of public pressure and activities of environmental nongovernmental organizations which try to take care of the drastically endangered landscape in the downstream part of the Cetina River. Despite their efforts, the release of the ecologically acceptable flow $\left(8 \mathrm{~m}^{3} \mathrm{~s}^{-}\right.$ $\left.{ }^{1}\right)$ from the Prančevići Reservoir is not respected. The small Prančevići HEPP started operating in 2017 with an installed discharge of $6 \mathrm{~m}^{3} \mathrm{~s}^{-1}$. 

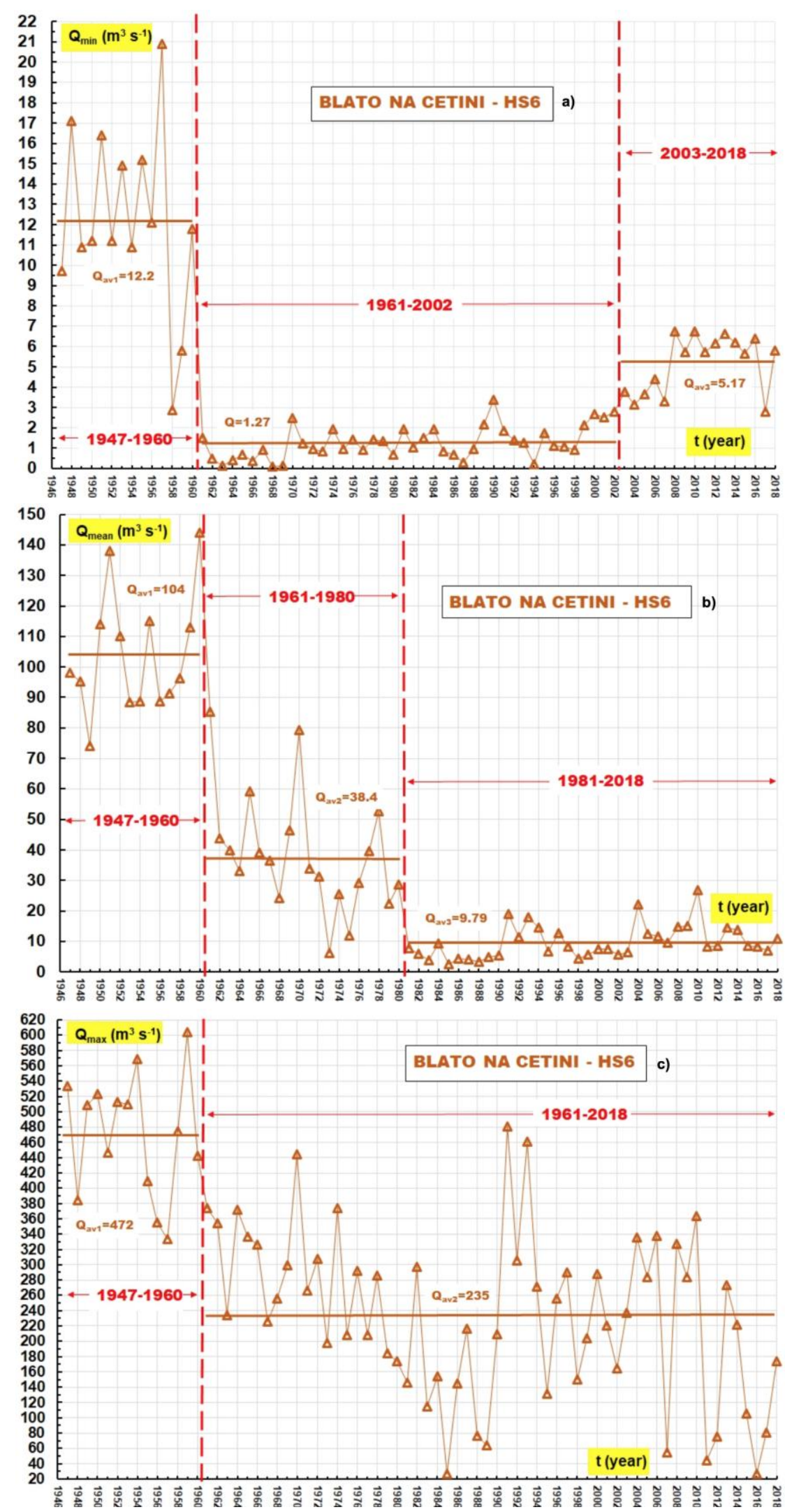

Figure 13: Time series of annual minimum (Figure 7a), mean (Figure 7b), and maximum (Figure 7c) discharges measured at hydrological stations Blato na Cetini (HS6) during the period from 1947 to 2018.

Slika 14: Časovna vrsta letnih minimalnih (slika 7a), srednjih (slika 7b) in maksimalnih (slika 7c) pretokov, izmerjenih na hidrološki postaji Blato na Cetini (HS6), v obdobju od 1947 do 2018. 
The mean annual time series (Figure $7 b$ ) is divided in the following three time subseries: (1) natural state 1947-1960; (2) after commissioning the first tunnel and pipeline from 1961 to 1980; (3) after commissioning the second tunnel and pipeline from 1981 to 2018 . The average values at these three subperiods show statistically significant differences. Results of the t-test for the average values of the first and the second subperiod are $p=6.3 \mathrm{E}-11$. Between the averages of the second and the third subperiods, the results of the t-test are $\mathrm{p}=2.6 \mathrm{E}-06$. Drastic drops are caused by the operation of the first and second tunnels and pipelines.

The maximum annual time series (Figure 7c) is divided into the following two time subseries: (1) natural state 1947-1960; (2) after building the Prančevići Reservoir 1961-2018. The average values at these two subperiods are statistically and significantly different. The results of the t-test are $\mathrm{p}=9.6 \mathrm{E}-11$. The drastic drop is caused by the operation of the Zakučac HEPP.

The amount of water resources downstream from the Prančevići Dam decreased drastically after the water diversion from the Prančevići Reservoir to Zakučac HEPP. Practically the last $40 \mathrm{~km}$ of the river have lost about $90 \%$ of the flow.

\subsection{Hydrological regime downstream from the Prančevići Dam}

Figure 8 shows the time series of annual minimum (Figure 8a), mean (Figure 8b), and maximum (Figure 8c) discharges measured at four hydrological stations (HS5, HS6, HS7, HS8) downstream from water diversion, from Prančevići Reservoir to Zakučac HEPP, during the period in which both hydroelectric plants were in operation from 1980 to 2018.

The time series of minimum annual discharges (Figure 8a) shows that the highest values occurred at the most downstream station, Tisne Stine (HS8), and the lowest values are at the Pavića Most (HS7) station. An increase in minimum as well as mean (Figure 8b) annual discharges at the Tisne Stine station is the consequence of the abundant permanent karst spring Studenci $(\theta$ in Figure 2) located $7 \mathrm{~km}$ upstream. It is assumed that water lost through the Cetina River bed in the section from Čikotina lađa (HS5) to Pavića most (HS7) goes back through the Studenci spring. It seems that losses occurred during low waters. This conclusion is supported by the graphical presentation given in Figure $8 b$, showing that the mean annual discharges at three stations (HS5, HS6, HS7) upstream from the Tisne Stine station practically have the same mean annual discharges. The time series of maximum annual discharges (Figure 8c) shows practically the same values at all four analysed hydrological stations.

\section{Conclusions}

Rivers all around the world are under severe amounts of stress. As they serve as the planet's irreplaceable bloodstream, they should be urgently protected. This action should be global. The situation is especially critical with rivers in karst regions, owing to their special hydrogeological, geomorphological, and environmental characteristics. In most cases it is difficult to differentiate the influence of anthropogenic from natural causes. In the case of the Cetina River and catchment, it should be stressed that the main drastic and dangerous changes were caused by different sources of human action. Rivers react to dam construction in various ways, reflecting changes in the relative balance between the quantity and type of transported sediment. In the case of Cetina River, this issue is not controlled and analysed at all. Dams disrupt natural river ecological connectivity.

The great problem is that the precise catchment area of the Cetina River had never been defined until now. As the catchment and river are drastically influenced by construction and other anthropogenic activities, it should be expected that the catchment will change in the future. Controlling this is of crucial importance because the Cetina River catchment is transboundary and its water resources management can be critical issue among the two countries (Croatia and Bosnia and Herzegovina).

It should be emphasised that climate change and human development lead to changes in water resources and watersheds, and the changes cause 
hydrological and ecological changes in rivers, resulting in a decline in water quality and difficulty in obtaining stable water resources (Lee et al., 2019).
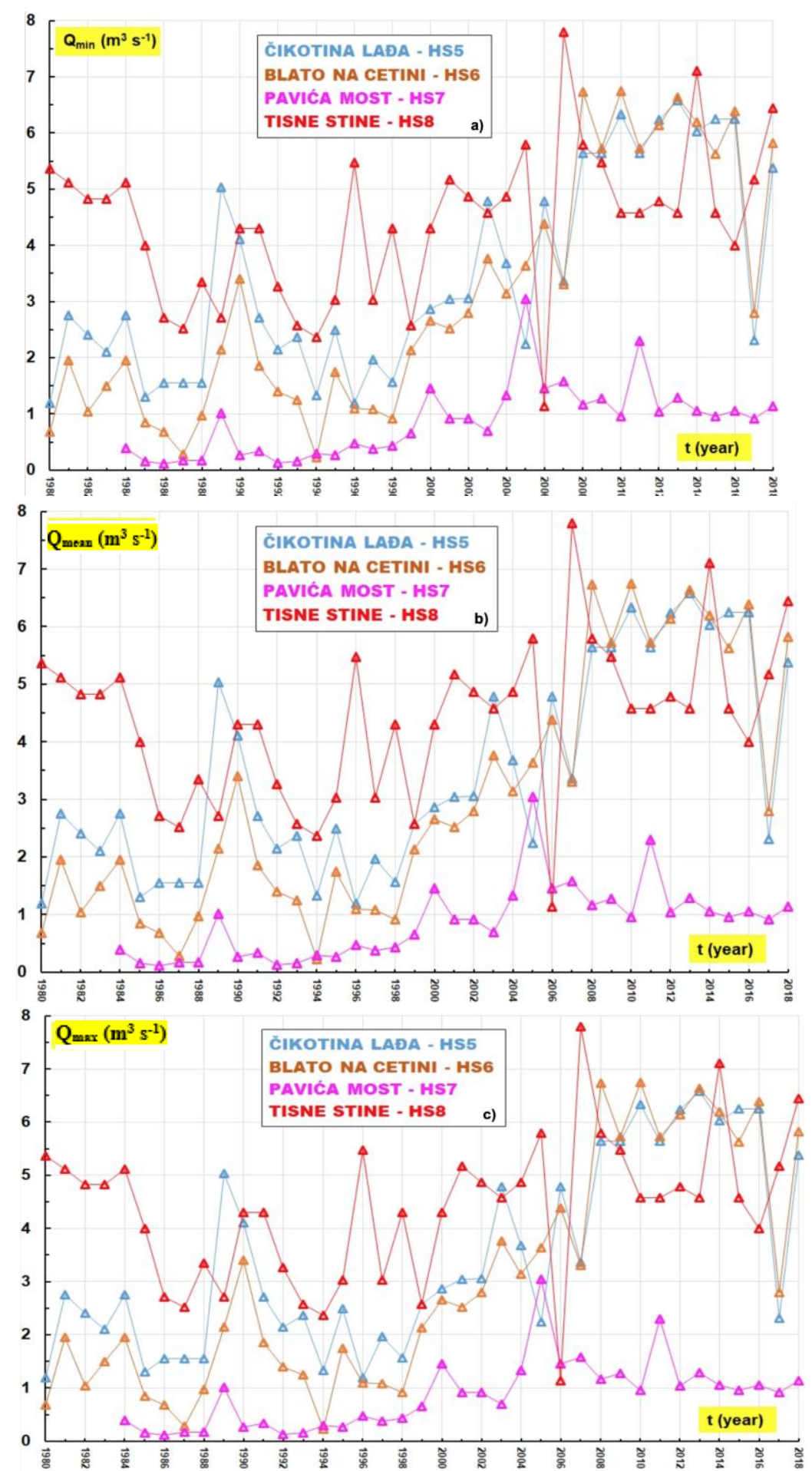

Figure 15: Time series of annual minimum (Figure 8a), mean (Figure 8b), and maximum (Figure 8c) discharges measured at four hydrological stations (HS5, HS6, HS7, HS8) downstream from the water diversion, from the Prančevići Reservoir to Zakučac HEPP during their period of common operation from 1980 to 2018.

Slika 16: Časovna vrsta letnih minimalnih (slika 8a), srednjih (slika 8b) in maksimalnih (slika 8c) pretokov, izmerjenih na štirih hidroloških postajah (HS5, HS6, HS7, HS8) dolvodno od preusmeritve iz akumulacije Prančevići na HE Zakučac med skupnimi deli v obdobju od 1980 do 2018. 
The human interventions described in the paper (dams, reservoirs, HEPP operation, water transfer) introduced changes to the Cetina River catchment, but this crucial issue has not been analysed at all. The effects of dams on downstream geomorphology are not controlled. Some of these channel changes adversely impact agriculture, native riverine ecosystems, and valued landscapes (Schmidt and Wilcock, 2008; Lele et al., 2013). The ecological acceptable flow is not respected.

Although the variations induced by climate changes in other variables of the hydrological cycle such as evaporation and precipitation were not considered in the study, human intervention in the watercourse can be identified as main driving force in the changes of the Cetina River's hydrological regime. The complex karst systems exhibit cascading movement of surface water from one polje to another, submerging in between the karst massif. Due to its porosity matrix, the karst massif acts as an additional reservoir in the system, reshaping the signal of spring discharges mostly governed by precipitation recharge and sinking water bodies in poljes. The reason why the springs along the left part of the Cetina (as well as the discharges along it) decreased and dried up should be attributed to anthropogenic actions in the indirect part of the catchment and the groundwater. The analysis of precipitation occurrence in the region and within the catchment area of the Cetina River showed that there is no evidence on significant statistical trends, neither increasing nor decreasing, over the period from the mid-twentieth century to the present. Even more, some isolated meteorological stations exhibit increase in annual rainfall.

An increase in air temperature over the last forty years has been observed in the whole basin. The direct part of the catchment experiences a more rapid increase in air temperatures than the indirect part which contributes the most in the basin recharge. The rising air temperatures do not significantly affect the deep karst groundwater (Kundzewicz and Doll, 2009; Green et al., 2011; Jia et al., 2017).

Consequently, by changing the natural state of local and regional groundwater movement as well as redirecting and accumulating surface flow not only in the orographic catchment but in the upper cascading poljes as well, the decline in the hydrological regime has spread along the whole watercourse of Cetina River.

Ecosystem services are benefits obtained directly or indirectly from river ecosystems and are closely linked to human well-being. Studying the trade-offs and synergies between ecosystem services upstream and downstream from dams is of great importance because such studies can help guide the coordinated development of ecosystems (Costanza et al., 1997).

The quantitative interpretation of water resources according to the dam construction on the transboundary river Cetina is essential to manage and maintain water resources, especially during dry seasons. The results of this study can be used as the basic data for efficient water management, protection of endangered landscapes, support of biological diversity, and sustainable management planning.

\section{Acknowledgements}

This research was supported through project KK.05.1.1.02.0024, "VODIME - Waters of Imotski region" a project financed by Croatian Government and the European Union through the European Structural Fund - within the call "Strengthening the applied research for climate change adaptation measures" KK.05.1.1.02.

This research was partially supported through project KK.01.1.1.02.0027, a project co-financed by the 571 Croatian Government and the European Union through the European Regional Development Fund - the 572 Competitiveness and Cohesion Operational Programme, contract number: KK.01.1.1.02.0027.

\section{References}

Atkinson, T. C. (1977). Diffuse flow and conduit flow in limestone terrain in Mendip Hills, Somerset Great Britain. Journal of Hydrology, 35, 93-100. https://doi.org/10.1016/0022-1694(77)90079$\underline{8}$. 
Barberá, J. A., Andreo, B. (2015). Hydrogeological processes in a fluviokarstic area inferred from the analyses of natural hydrogeochemical tracers: The case study of eastern Serrania de Ronda (S Spain). Journal of Hydrology, 523, 500-514. https://doi.org/10.1016/j.jhydrol.2015.01.080.

Baučić, I. (1967). Cetina - razvoj reljefa i cirkulacija vode $u$ kršu (Cetina - development of relief and water circulation in karst). Acta Geographica Croatica, 6(1), 5-167. (in Croatian)

Bonacci, O. (1987). Karst Hydrology with Special References to the Dinaric Karst, Springer, Berlin.

Bonacci, O. (1999). Water circulation in karst and determination of catchment areas: example of the River Zrmanja. Hydrological Sciences Journal, 44(3), 373-385. https://doi.org/10.1080/02626669909492233.

Bonacci, O. (2001). Analiza klimatskih promjena u slivu Cetine (Climate change analysis in the Cetina basin). Građevinski fakultet: Split, Croatia. Unpublished Design. (In Croatian)

Bonacci, O. (2004). Hazards caused by natural and anthropogenic changes of catchment area in karst. Natural Hazards and Earth System Sciences, 4, 655-661. $\quad$ https://doi.org/10.5194/nhess-4-6552004.

Bonacci, O. (2013). Ponors, Poljes and Their Catchments in: Shroder, J. F., Frumkin, A. (Eds.), Treatise on Geomorphology, Vol 6, Karst Geomorphology; Academic Press, San Diego, CA, USA, pp. 112-120. https://doi.org/10.1016/b978-012-374739-6.00103-2.

Bonacci, O. (2015). Karst hydrogeology/hydrology of dinaric chain and isles. Environmental Earth Sciences, 74, 37-55. https://doi.org/10.1007/s12665-014-3677-8.

Bonacci, O., Andrić, I. (2008). Sinking karst rivers hydrology: case of the Lika and Gacka (Croatia). Acta Carsologica, 37(2-3), 185-196. https://doi.org/10.3986/ac.v37i2.146.

Bonacci, O., Andrić, I. (2010). Impact of inter-basin water transfer and reservoir operation on a karst open streamflow hydrological regime: an example from the Dinaric karst (Croatia). Hydrological
Processes, $\quad$ 24(26), 3852-3863. https://doi.org/10.1002/hyp.7817.

Bonacci, O., Buzjak, N., Roje-Bonacci, T. (2016). Changes in hydrological regime caused by human intervention in karst: the case of the Rumin Springs. Hydrological Sciences Journal, 61(13), 2387-2398. https://doi.org/10.1080/02626667.2015.1111518.

Bonacci, O., Gottstein, S., Roje-Bonacci, T. (2009). Negative impacts of grouting on the underground karst environment. Ecohydrology, 2, 492-502. https://doi.org/10.1002/eco.90.

Bonacci, O., Oštrić, M., Roje-Bonacci, T. (2018). Water resources analyses of the Rječina karst spring and river (Dinaric karst). Acta Carsologica, 47(2/3), 123-137. https://doi.org/10.3986/ac.v47i2-3.5182.

Bonacci, O., Roje-Bonacci, T. (2003). The influence of hydroelectrical development on the flow regime of the karstic river Cetina. Hydrological Processes, 17, 1-15. https://doi.org/10.1002/hyp.1190.

Bonacci, O., Roje-Bonacci, T. (2012). Impact of grout curtains on karst groundwater behaviour: an example from the Dinaric karst. Hydrological Processes, 26(18), 2765-2772. https://doi.org/10.1002/hyp.8359.

Bonacci, O., Roje-Bonacci, T. (2015). Drastic hydrological changes caused by hydroelectrical development in karst: a case of the karst river Zrmanja (Croatia). Environmental Earth Sciences, 74(9), 6767-6777. https://doi.org/10.1007/s12665015-4688-9.

Bonacci, O., Željković, I., Galić, A. (2013). Karst rivers' particularity: an example from Dinaric karst (Croatia/Bosnia and Herzegovina). Environmental Earth Sciences, 70, 963-974. https://doi.org/10.1007/s12665-012-2187-9.

Calò, F. M., Parise. M. (2006). Evaluating the human disturbance to karst environments in southern Italy. Acta Carsologica, 35(2), 47-56. https://doi.org/10.3986/ac.v35i2-3.227.

Cavalera, T., Gilli, E. (2009). The submarine river of Port Miou (France), a karstic system inherited from the Messinian deep stage. Geophysical Resarch Abstracts, 11, EGU 2009-5591. 
Costanza, R., d'Arge, R., de Groot, R. S., Farber, S., Grasso, M., Hannon, B., Limburg, K., Naeem, S., O’Neill, R. V., Paruelo, J., Raskin, R. G., Suttonkk, P., van den Belt, M. (1997). The value of the world's ecosystem services and natural capital. Nature, 387(6630),

253-260.

http://doi.org/10.1038/387253a0.

Field, M. (2002). A Lexicon of Cave and Karst Terminology with Special References to Environmental Karst Hydrology, EPA National Center for Environmental Assessment, Washington, DC, USA.

Ford, D., Williams, P. (2007). Karst Hydrogeology and Geomorphology; Wiley and Sons, Chicester, UK. http://doi.org/10.1002/9781118684986.ch6.

Green, T. R., Taniguchi, M., Kooi, H., Gurdak, J. J., Allen, D. M., Hiscock, K. M., Treidel, H., Aureli, A. (2011). Beneath the surface of global change: Impacts of climate change on groundwater. Journal of Hydrology, 405, 532-560. http://doi.org/10.1016/j.jhydrol.2011.05.002.

Hess, J. W., Wells, S. G., Quinlan, J. F., White, W. B. (1989). Hydrogeology of the South-Central Kentucky karst. In: White, W. B., White, E. L., (Eds), Karst hydrology concepts from the Mammoth Cave area, Van Nostrand Reinhold: New York, NY, USA; pp. 15-63. https://doi.org/10.1007/978-1-4615-7317-3 2.

Huđek, H., Žganec, K., Pusch, M. T. (2020). A review of hydropower dams in Southeast Europe distribution, trends and availability of monitoring data using the example of a multinational Danube catchment subarea. Renewable and Sustainable Energy Review, 117, 109434. https://doi.org/10.1016/j.rser.2019.109434.

Jia, Z., Zang, H., Zheng, X., Xu, Y. (2017). Climate change and its influence on the karst groundwater recharge in the Jinci Spring Region, Northern China. Water, 267. https://doi.org/10.3390/w9040267.

Kendall M. G. (1975). Rank Correlation Methods 4th edition, Charles Griffin, London, Great Britain. https://doi.org/10.2307/2986801.
Kundzewicz, Z. W., Doll, P. (2009). Will groundwater ease freshwater stress under climate change. Hydrological Sciences Journal, 54, 665675. https://doi.org/10.1623/hysj.54.4.665.

Lee, G., Lee, H. W., Yong, S. L., Jung, H. C., Jae, E. Y., Lim K. J., Kim, J. (2019). The effect of reduced flow on downstream water systems due to the Kumgangsan Dam under dry conditions. Water, 11, 739. https://doi.org/10.3390/w11040739.

LeGrand, H. E. (1983). Perspective on karst hydrology. Journal of Hydrology, 61(1-3), 343-355. https://doi.org/10.1016/0022-1694(83)90257-3.

Lele, S., Springate-Baginski, O., Lakerveld, R., Deb, D., Dash, P. (2013). Ecosystem services origins, contributions, pitfalls, and alternatives. Conservation \& Society, 11(4), 343-358. https://doi.org/10.4103/0972-4923.125752.

López Chikano, M., Calvache, M. L., MartinRosales, W., Gisbert, J. (2002). Conditioning factors in flooding in karstic polje - the case of Zafarraya Polje (South Spain). Catena, 49, 331-352. https://doi.org/10.1016/s0341-8162(02)00053-X.

Magdalenić, A. (1971). Hidrogeologija sliva Cetine. Krš Jugoslavije (Hydrogeology of the Cetina basin. Karst of Yugoslavia), 7(4), 89-169. (in Croatian).

Mann, H. B. (1945). Non-parametric test of randomness against trend. Econometrica, 13(3), 245-259. https://doi.org/10.2307/1907187.

Milanović, P. (1981). Karst Hydrogeology, Water Resources Publication: Littleton, CO, USA.

Morán-Tejeda, E., Lorenzo-Lacruz, J., LópezMoreno, J. I., Ceballos-Barbancho, A., Zabalza, J., Vincente-Serrano, S. M. (2012). Reservoir management in the Duero Basin (Spain): Impact on river regimes and the response to environmental change. Water Resources Management, 26, 21252146. http://doi.org/10.1007/s11269-012-0004-6.

Prelovšek, M., Turk, J., Gabrovšek, F. (2008). Hydrodynamic aspect of caves. International Journal of Speleology, 37(1), 11-26. https://doi.org/10.5038/1827-806x.37.1.2.

Sackl, P., Durst, R., Kotrošan, D., Stumberger, B. (Eds.) (2014). Dinaric Karst Poljes - Floods for Life, EuroNature: Radolfzell, Germany. 
Schmidt, J. C., Wilcock, P. R. (2008). Metrics for assessing the downstream effects of dams. Water Resources Research, 44, W04404. https://doi.org/10.1029/2006wr005092.

Srebrenović, D. (1963). Hidrologija Sliva Cetine. ( Hydrology of the Cetina Basin.) Faculty of Geodesy University of Zagreb: Zagreb, Croatia. Unpublished Design. (in Croatian).

Stepinac, A. (1980). Vodoprivredna osnova Cetine. (Water management base of Cetina.) Elektroprojekt: Zagreb, Croatia. Unpublished Design. (in Croatian).

Terzić, J., Marković, T., Lukač-Reberski, J. (2014). Hydrogeological properties of a complex Dinaric karst catchment: Miljacka Spring case study. Environmental Earth Sciences, 72, 1129-1142. https://doi.org/10.1007/s12665-013-3031-6.
UNEP/MAP/PAP (2000) River Cetina Watershed and the Adjacent Coastal Area: Environmental and Socio-economic Profile, Priority Action Programme: Split, Croatia.

Vučković, I., Božak, I., Ivković. M., Jelenčić, M., Kerovec, M., Popijač, A., Previšić, A., Širac, S., Zrinski, I., Kučinić, M. (2009). Composition and structure of benthic macroinvertebrate communities in the Mediterranean karst river the Cetina and its tributary the Ruda, Croatia. Natura Croatica, 18(1), 49-82.

Yuan, D. (1991). Karst of China, Geological Publishing House: Beijing, China. 